\title{
PLATÃO E CRÁTILO: DO ÓNOMA AO LÓGOS
}

DION DAVI MACEDO*

Departamento de Filosofia da Universidade São Judas

\begin{abstract}
RESUMO: Trata-se de entender o estatuto da linguagem em Platão, à luz da ênfase conferida ao domínio da verdade (alétheia) e do Ser (eînai; tò ón), aquele domínio que condiciona, determina e ultrapassa a linguagem, e da impossibilidade de ignorar as conexóes e implicações epistemológicas vinculadas ao complexo tema do estabelecimento das relações entre as palavras e as coisas.
\end{abstract}

PALAVRAS-CHAVE: linguagem; teoria do conhecimento; Crátilo; Heráclito; Platão.

Falar sobre palavras com palavras é tão complicado como entrelaçar os dedos e assim querer esfregá-los, quando somente quem os mexe pode distinguir os dedos que têm comichão dos que ajudam a acalmar os que têm prurido.

(Agostinho De Magistro V, 14)

O estatuto da linguagem em Platão ${ }^{1}$ implica uma teoria do conhecimento, através de um percurso que principia pelo Crátilo (num plano que é apenas aparentemente lingüístico), passa pelo Teeteto (num círculo problemático que formula a interdependência entre linguagem e conhecimento) e que se resolve no Sofista (onde são analisados os gêneros supremos $-\mu \varepsilon \dot{\varepsilon} \imath \sigma \tau \alpha \gamma \dot{\varepsilon} v \alpha-q u e$ constituem a estrutura do Ser). Esse estatuto e esse percurso enlaçam, num único movimento lógico, a essência que preside as palavras, no Crátilo (439 a), e a essência que preside as coisas, no Fédon.

Tais implicações articulam-se com o regime/modelo de verdade epistêmico e ontológico, para Platão próprio à filosofia, e que confere o suporte para todo conhecimento. Nós estamos, assim, na raiz do realismo das significações: é a subordinação ao ser, do qual é conveniente expressão, que confere à linguagem 
seu peso e sua legitimidade. A linguagem repousa no quadro das determinações ontológicas do $\varepsilon \hat{i} \delta$ o $\varsigma$, que é a sua condição de possibilidade.

Com efeito, uma das fontes da ontologia platônica é a recusa do subjetivismo e do historicismo da linguagem. Platão procura desmontar, contra Crátilo e contra Hermógenes, a idéia segundo a qual a linguagem é dependente unicamente do $\check{\varepsilon} \theta 0 \varsigma$ vigente e da soberania do homem, seja ela privada ou pública. A realidade da essência surge desde o início, na causa do problema da linguagem. $O$ pensamento platônico, instaurando, talvez pela primeira vez, uma teoria da linguagem, encaminha em todos os sentidos o processo que conduz da potência e eficácia das palavras (segundo a interpretação convencionalista de Hermógenes), por um lado, e da potência e eficácia das coisas (conforme o viés naturalista de Crátilo), ao primado do Ser. Diz Platão:

As coisas têm, por elas mesmas, um ser permanente, que não é relativo a nós nem depende de nós (Crátilo 386 e).

É sob a égide do Ser que Platão procurara refutar, a um só tempo, a oposição entre $\varphi$ ú $\sigma \iota \varsigma$ e $v o ́ \mu o \zeta^{2}$, e é a partir desse princípio fundante do real que se procura determinar a relação entre as palavras e as coisas.

Lembre-se, antes de mais nada, que do diálogo espera-se menos uma teoria do que um exercício. É lógico que há coisas que ele afirma, mas Sócrates joga, esconde cartas na manga. Mas é exatamente por isto que num diálogo, como um exercício filosófico, é fundamental fazer e refazer o vaivém. Ainda mais num diálogo como o Crátilo, que tematiza a si mesmo.

Seguindo o título que me foi sugerido, proponho uma leitura dos movimentos finais do diálogo, aqueles em que Sócrates e Crátilo disputam sobre o naturalismo da linguagem. Com efeito, de 428a até 440e, discute-se a procedência natural da linguagem, procedência compreendida como plena concordância entre as palavras e as coisas.

Crátilo defende a naturalidade da linguagem fundamentado numa posição derivada de Heráclito, ou melhor, de uma determinada compreensão de Heráclito, que não cabe aqui explicitar no momento 3 . $\mathrm{O}$ heraclitismo do Teeteto dá conteúdo à teoria do conhecimento, do mesmo modo que, no Crátilo, constitui o horizonte da teoria da linguagem. Com efeito, Hermógenes afirmara, no início do diálogo que, para Crátilo, "a adequação do nome, para cada um dos entes, é gerada por natureza"

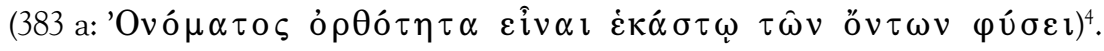


Afora a recorrência desta compreensão no Crátilo, Sócrates volta aos termos cratilianos, contra Hermógenes, e pode afirmar que ele "diz a verdade quando diz que é por natureza que os nomes são dados às coisas” (390 e: $\dot{\alpha} \lambda \eta \theta \hat{\alpha}$

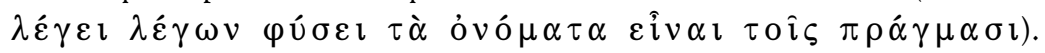

Trata-se de uma proposição subordinada à idéia segundo a qual "todas as coisas passam e nada permanece" (402 a: $\pi \dot{\alpha} \nu \tau \alpha \chi \omega \rho \varepsilon \hat{\imath} \kappa \alpha \grave{\imath}$ o $u \dot{\delta} \nu \mu \varepsilon \dot{\varepsilon} v \varepsilon \imath$; cf. 411 b-c). No fundo, a ligação entre a teoria do fluxo universal e a proposição de que "é por natureza que os nomes são dados às coisas" só é inteligível quando se compreende que, para Crátilo, todos os nomes são justos porque a linguagem pode imitar as coisas e porque o onomaturgo, em sua infalibilidade sobre-humana não teria podido se enganar.

Há, assim, a idéia de uma identidade entre palavra e coisa, como se a linguagem constituísse uma sorte de duplo do mundo. É este o núcleo problemático que gostaria de discutir.

Sócrates principia por buscar um fundamento comum a partir do qual poderia refutar a posição cratiliana. Esse fundamento é exemplarmente definido por Sócrates, que o faz depender do problema da verdade. Em 385 b, Sócrates já definira como verdadeiro dizer o ser $(\tau \grave{\alpha}$ ő $v \tau \alpha)$ tal como ele é, e falso dizer o ser como ele não é. Esta idéia reaparece em 428 e, quando Sócrates ressalta que a adequação do nome está em mostrar a coisa tal qual ela é, em fazer ver a natureza da coisa.

Esta definição é aceita por Crátilo, que não imagina a armadilha na qual estará se lançando. Para ele, com efeito, por não haver solução de continuidade entre o nome e a coisa, e pelo fato da palavra ser constituída como ato natural e inerente à própria coisa, a proposição socrática não apresenta problemas.

Num testemunho de ingenuidade, Crátilo aceita o elogio de Sócrates e admite aceitá-lo como seu discípulo.

Se ambos, Sócrates e Crátilo, partem desse fundamento comum, é de se notar que a compreensão que cada um tem é de tal modo distinta que não se pode confundir uma posição com a outra. A aparente opinião comum esconde uma distância considerável e mascara um solo interpretativo inconciliável, como veremos.

Pensemos na imagem de um cerco militar: é assim que Sócrates rodeia Crátilo e fá-lo dizer o que pretende. Se podemos definir a posição de Crátilo, é muito mais pelo papel negativo de Sócrates do que por qualquer proposição sua que possa ser tomada como exemplo. É um jogo pelo qual a negativa ou a afirmativa de Crátilo deixam entrever a sua posição. Como, de resto, desde o início do diálogo, pois são Hermógenes e Sócrates que enunciam a sua posição. 
Se o mundo é heraclitiano, então nada se pode dizer de verdadeiro, e conseqüentemente o filósofo deverá calar-se. Dizer que não se conseguiria entrar duas vezes no mesmo rio é simplesmente dizer - validando a equivalência socrática dos entes ao rio - que não se conseguiriam perceber duas vezes os mesmos entes. Ora, dizer como o Crátilo aristotélico, que se deve apenas apontar as coisas, é dar a entender que é impossível fixar o rio, ou que a corrente não tem margens: não apenas os entes, quer dizer, os sensíveis, fluem, mas também o pensamento, ou seja, a sensação, se altera.

Eis porque um Crátilo conseqüente deve simplesmente apontar. $\mathrm{O}$ silêncio de Crátilo e o seu sentido filosófico são admitidos por Platão. Logo no início do diálogo, é Hermógenes quem diz que ele "finge abrigar no seu interior um pensamento, mas nada diz" (384 a) e já bem próximo do final, quando Sócrates diz que considera "o seu silêncio ( $\sigma$ l $\gamma$ ท́) como uma aprovação" (435 b).

Aí Crátilo pouco fala: um quinto do diálogo. No resto do tempo fazem-no falar, falam por ele. Segundo toda a aparência, Crátilo pensa, mas não diz nada.

É quando Sócrates questiona Crátilo sobre a relação entre pintura e coisa e entre palavra e coisa que melhor se percebe o seu ponto de vista. Ao estabelecer diferença, em 430 a, entre nome e coisa, Sócrates faz com que Crátilo aceite

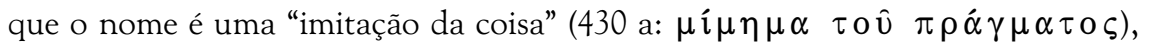
da mesma maneira que "as pinturas imitam certas coisas" (430 b: $\tau \grave{\alpha}$ $\left.\zeta \omega \gamma \rho \alpha \varphi \eta^{\prime} \mu \alpha \tau \alpha \quad \mu \imath \mu \eta \dot{\eta} \mu \alpha \tau \alpha \quad \pi \rho \alpha \gamma \mu \alpha \tilde{\tau} \omega \nu\right)$.

Isto feito, é um passo para que Sócrates comece a rever a posição de Crátilo, fazendo com que ele hesite entre aceitar igualmente a teoria da imitação para o nome e para a pintura. Pois se para ele há pinturas melhores e piores, o mesmo não acontece com os nomes, com as palavras, com o discurso. Para Crátilo, todos os legisladores são bons e, por conseguinte, todos os nomes são igualmente bons, não sendo possível sequer falar falso.

A teoria de que é impossível falar falso, ou melhor, que o não ser é indizível, deve a sua origem aos eleatas e tornou-se um lugar comum da sofística. Segundo Aristóteles, um dos seus adeptos foi Antístenes, a quem Platão, talvez, tenha aqui em vista. Sobre esta teoria, há uma passagem do Sofista que merece ser lida:

Mostrar e parecer sem ser, dizer algo sem, entretanto, dizer com verdade, são maneiras que trazem grandes dificuldades, tanto hoje, como ontem e sempre. Que modo encontrar, na realidade, para dizer ou pensar que o falso é real sem que, já ao proferi-lo, nos encontremos enredados na contradição? (236 e $)^{5}$. 
Se o que Crátilo confunde, segundo Platão, diz respeito ao domínio ou às formas da $\mu i ́ \mu \eta \imath \iota$, o que importa entender é o estatuto da imagem, qual o seu papel em relação "à forma do ser" (386 e: $\varepsilon \hat{i} \delta$ o $\zeta \tau \hat{\omega} v$ ỏ $v \tau \omega v)$. Sócrates retoma uma idéia já trabalhada anteriormente, a da complexidade da linguagem, ou melhor, a linguagem como um sistema de complexidade crescente. Com efeito, teríamos um sistema de sons elementares ou palavra, de palavras ou frase, de frases ou discurso:

Nós devemos distinguir, então, primeiro as vogais; em seguida, os elementos privados e som e de ruído de todos os outros, segundo as suas espécies; e, depois os elementos que não são vocálicos nem mudos. [...] Assim também nós aplicaremos os elementos às coisas, um único a uma única, aquele que for tido por necessário, ou muitos conjuntamente, formando, desta maneira, o que chamamos sílabas e, depois, ajuntando as sílabas, delas faremos os nomes e as frases, dos quais comporemos, então, um grande e belo conjunto, como o ser vivo há pouco reproduzido pela pintura - comporemos o discurso por meio da arte dos nomes $(424 \mathrm{c}-425 \mathrm{a}$; cf. Teet. $204 \mathrm{a}-$ 205 a).

Quando Sócrates retoma a idéia da complexidade da linguagem, ele a aplica contra a defesa que Crátilo faz da impossibilidade de dizer o falso. E aí então temos a armadilha na qual Crátilo cai, pela possibilidade de se atribuir nomes equivocamente, referindo-se a um homem como se fosse a uma mulher, por exemplo.

A complexidade da linguagem retorna em uma outra dimensão: trata-se então, através de cada um dos elementos que a compõem, de estabelecer a veridicidade do discurso, ou, em outras palavras, das condições de possibilidade do discurso verdadeiro. Pois, para Sócrates, a palavra e o discurso não devem limitar-se à aparência do mundo, mas visar a essência da realidade.

Há uma dupla exigência na compreensão da linguagem como $\mu$ í $\mu \eta \sigma \iota$ : do lado do significado, deve-se imitar somente a essência do objeto, do lado do significante, deve-se imitar somente os fonemas:

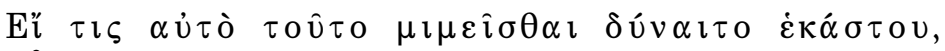

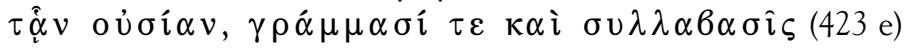

Por meio das letras e das sílabas [pode-se] imitar a essência própria de cada coisa. 
A definição socrática do nome como imitação da essência da coisa por meio de letras e sílabas exclui toda subserviência, pois a imitação pretendida não é perfeita. Sócrates afirma isto pois entende (432 d) que, se houvesse identidade entre a imagem e a coisa, elas não poderiam ser distinguidas. É a bem conhecida fórmula socrática contra a pintura perfeita, que seria um verdadeiro duplo de seu modelo, e contra a nomeação perfeita, que faria da linguagem um duplo da realidade. Do Banqueteà República, do Crátilo ao Sofista e passando pelo Teeteto, desenrola-se a tese segundo a qual é necessário que a cópia seja deficiente em relação ao modelo.

Parece haver mais ironia que verdadeira controvérsia nesta fórmula, que pode funcionar como argumento contra Crátilo e polêmica contra Heráclito. Se Crátilo acredita na infalibilidade do onomaturgo, todos os nomes são justos e os nomes que não são justos (como o de Hermógenes), não são nomes, não passam de ruídos, simplesmente. Como não há identidade no fluxo, não pode haver identidade na linguagem.

Se tudo passa, nada se pode ligar com correção a coisa nenhuma, nem

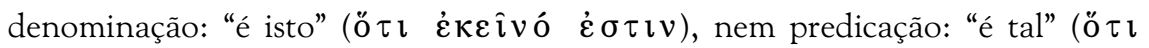
$\tau$ o lo v̂ $\tau$ ov) (439 d). Não se trata apenas de uma projeção do mal-estar de quem conhece ante o conhecido, mas de uma tripla e radical impossibilidade:

Se tudo se transforma continuamente, quer dizer, muda de forma ( $\varepsilon \hat{i} \delta \circ \varsigma$ ), então não se poderá ter nem conhecimento (o ủ $\ddot{\alpha} v$

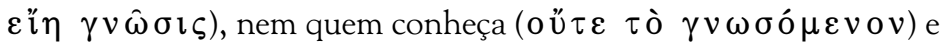

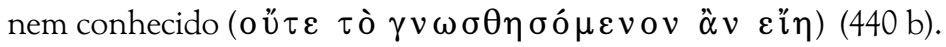

Platão procura mostrar que o heraclitismo generalizado conduz à impossibilidade simultânea do ser e do discurso. É preciso então, ensina Sócrates contra Crátilo, partir das coisas para que o conhecimento seja possível: somente através dos nomes não conhecemos sequer estes. Para decidir entre o modelo e a cópia, é necessário ir do modelo à cópia, não o contrário. A relação entre as coisas e os nomes, como relação de verdade, exige que se passe da verdade das coisas à verdade das palavras, uma verdade secundária e dependente. Ela supõe a antecedência da verdade em relação ao dizer verdadeiro. É neste sentido que se deve entender e admitir a possibilidade de compreender as coisas sem os nomes, isto é, estabelecer a impossibilidade de compreender os nomes sem as coisas. 
Le discours est le discours vrai, celui qui, par exclusion du discours faux, 'dit les choses comme elles sont, et les dit d'un objet ou d'un sujet aux quels le discours est ordonné! En combinant leurs effets, la logique de la proposition, la linguistique de l'attribution ou du discours et la sémantique de la présence ont donc permis de quitter la tyrannie rhétorique du nom, de passer au privilège du lógos et d'assurer la suprématie de l'être, c'està-dire, la primauté de ce qui est comme il est, en quoi consiste la vérité (Joly, 1980, p. 188).

Platão opera o reconhecimento do drama humano, dividido entre a sensação e a inteligência, no qual a transcendência permanece como o fundamento e o horizonte da investigação. E ele o faz ao tentar comprender a linguagem em três grandes eixos: com Hermógenes, com o jogo das etimologias e com Crátilo. Mas ele o faz notadamente ao reconhecer que não se pode sair da linguagem para falar da linguagem: é um círculo do qual não há possibilidade de escapatória.

A opacidade da linguagem é o próprio termo da investigação sobre a linguagem. $O$ preconceito que o diálogo tenta desentranhar é o da transparência da linguagem, como se ela pudesse ser algo imediato ao mundo. Não para Platão, de qualquer maneira, pois ela deve apontar para uma instância superior. Há uma expressão francesa, mise-en-abîme, que pode ajudar-nos a compreender a encruzilhada em que a linguagem nos põe: ela é a tradução francesa de alguns termos utilizados por Heidegger ao retomar Hegel: Grund(fundamento), Abgrund (abismo) e zu Grund gehen (ir até o fundamento).

$\mathrm{Na}$ tentativa de se estabelecer uma relação entre a linguagem e a realidade, para se efetuar a compreensão de tal relação, seria necessário que o ser humano estivesse fora da linguagem e fora da realidade; como isso não é possível, irrompe a idéia de um abismo, de um precipício. Mas devemos, espantosamente, apoiar-nos nesse abismo para o entendermos. "Quem cai deve apoiar-se no solo onde caiu", é a sentença de Agostinho.

\section{Notas}

* Graduado em Grego pela FFLCH-USP, Mestrando em Filosofia pelo Programa de Pós-Graduação da PUC-SP e Professor de Filosofia do Departamento de Filosofia da Universidade São Judas. 
1 A linguagem, para Platão, é entendida como a relação entre as palavras e as coisas e não tem autonomia em relação aos outros domínios do conhecimento (ética, estética e a teoria do conhecimento) e em relação à própria realidade. Será a partir de Frege, com a distinção entre sentido (Sinn) e referência (Bedeutung), que se inicia a discussão lógica da linguagem, tomada autonomamente, onde o significado é visto a partir do lugar das palavras no interior de um cálculo formal. Cf. Gottlob Frege, Lógica e filosofia da linguagem, pp. 559-586.

2 Esta discussão teve uma fortuna crítica notável. A favor da tese convencionalista estão, por exemplo, John Locke, Ensaios sobre o entendimento humano(1690), Ferdinand Saussure, Curso de Lingüística Geral (1916); a favor da naturalista, encontra-se, por exemplo, Walter Benjamin, com os ensaios "Sobre a linguagem em geral e a linguagem dos homens" e "Sobre a faculdade mimética" (tradução de Susana Kampff Lages) in: Susana Kampff Lages, Melancolia e tradução: Walter Benjamin e a "Tarefa do tradutor”, Tese de doutorado em Comunicação e Semiótica. São Paulo: PUCSP, 1996.

3 Para uma leitura aprofundada, veja-se, entre tantos outros, o excelente estudo de Giuseppina Grammatico Amari, Una aproximación ao lógos heracliteo.

4 Aristóteles, na Metafísica, livro $\Delta$, conta que Crátilo, tendo levado às últimas conseqüências a sentença "em rio não se pode entrar duas vezes no mesmo" (fr. 91), de Heráclito, achava que não era possível entrar nem sequer uma única vez, recusandose até a falar, apenas apontando com o dedo.

5 Leia-se, a propósito, o artigo de Francis Wolff, "Deux destins possibles de l'ontologie: la voie catégoriale et la voie physique", a aparecer na revista Analytica, da UFRJ.

\section{REFERÊNCIAS BibliográficAs}

ANDRADE, R. G. Platão: o cosmo, o homem e a cidade - um estudo sobre a alma. Petrópolis: Vozes, 1994.

BASSETTO, B. F. O significado de "filólogo" para gregos e romanos. Classica. Araraquara, Suplemento 2, p. 109-116, 1993.

BLIKSTEIN, I. Crátilo e Hermógenes: motivação versus arbitrariedade do signo lingüístico. Estudos de Filologia e Lingüística (em homenagem a Isaac Nicolau Salum). São Paulo: T. A. Queiroz Editor / EDUSP, 1981. p. 27-37.

BOYANCÉ, P. La doctrine d'Euthyphron dans le Cratyle. Revue des Études Grecques. Paris, LIV, p. 141-175, 1941.

CASSIN, B. O dedo de Crátilo. Tradução de J. G. Trindade Santos. Análise. Lisboa, 7, p. 3-14, 1987.

DRUART, T.-A. La Stoicheïologie de Platon. Revue Philosophique de Louvain. Louvain, 73 (18), p. 243-262, mai 1975. 
GAGNEBIN, J. M. Morte da memória, memória da morte: da escrita em Platão. In: . Sete aulas sobre linguagem, memória e história. Rio de Janeiro: Imago, 1997. p. 49-67.

GENETTE, G. Mimologiques. Voyage en Cratylie. Paris: Éditions du Seuil, 1976.

GOLDSCHMIDT, V. Essai sur le "Cratyle": contribution a l'histoire de la pensée de Platon. Paris: J. Vrin, 1982.

GRAMMATICO, G. Una aproximación ao lógos heracliteo. Clássica. São Paulo, 5/6, p. 15-31, 1992/1993.

HANSEN, J. A. Ortônimo, sinônimo, homônimo: retórica do anônimo. Clássica. São Paulo, 5/6, p. 33-56, 1992/1993.

JOLY, H. Le renversement platonicien (lógos, epistême, pólis). 2 ed. Paris: J. Vrin, 1980.

JURET, A. Les idées et les mots: essai de philosophie linguistique - la formation des idées observée dans la formation des mots. Paris: J. Vrin, 1960.

LADRIÈRE, J. A articulação do sentido. Tradução e prefácio de S. T. Muchail. São Paulo: EDUSP/E.P.U., 1977.

MENEZES, P. Onascimento da semiótica: conhecimento, enigma e poesia. Trabalho inédito. São Paulo, 1996.

PAVIANI, J. Escrita e linguagem em Platão. Porto Alegre: Edipucrs, 1993.

PÉREZ, O. E. Protágoras "o homem é medida de todas as coisas": episteme, linguagem e aretê. Dissertação de Mestrado em Filosofia. São Paulo: PUCSP, 1984.

PLATÃO. Cratyle. Texte établi et traduit par L. Méridier. Paris: Les Belles Lettres, 1989.

. Crátilo. Tradução de C. A. Nunes. 2 ed. Belém: Editora UFPa, 1988.

PLATONE. Cratilo. Presentazione, traduzione e note di M. L. Gatti. In:

Tutti gli scritti. A cura di Giovanni Reale. 4 ed. Milano: Rusconi, 1994. p. 131-190.

REALE, G. Per una nuova interpretazione di Platone: rilettura della metafisica dei grandi dialoghi alla luce delle "Dottrine non scritte". Milano: Vita e Pensiero, 1995.

SÁ, O. A nomeação do ser. Cruzeiro Semiótico. Porto, 18-19, p. 195-198, janeiro/ julho 1993.

SOUZA NETTO, F. B. O conceito de dialética na filosofia grega: ensaio de delimitação de um problema.In: Favaretto, C. F.; Bogus, M. L. M.; Véras M. 
P. B. (org.). Epistemologia das Ciências Sociais. São Paulo: EDUC (Ed. da PUCSP) / FAPESP, 1984. p. 9-26.

MACEDO, Dion Davi. Platon et Cratyle: de l'ónoma au lógos.

RÉSUMÉ: Ils'agit de reconnaître la place que Platon donne au langage quand il tient compte de la vérité (alétheia) et de l'être (eînai; tò ón), c'est à dire, de ce domaine qui subordonne, détermine et surpasse le langage, et quand il envisage la complexe question épistemologique de l'établissement des liens des mots aux choses.

MOTS-CLÉS: langage; théorie de la connaissance; Cratyle; Héraclite; Platon. 